\title{
The Development of Supplementary Teaching Material for Ibnu Hadjar's Biography to Improve Collagers' Critical Thinking Skills of History Education
}

\author{
Febri Irwandi $^{1}$, Joko Sayono ${ }^{1}$, R Reza Hudiyanto ${ }^{1}$ \\ ${ }^{1}$ State University of Malang
}

\begin{tabular}{l}
\hline ARTICLE INFO \\
\hline Article History: \\
Accepted: $31-12-2019$ \\
Published: $21-10-2020$ \\
\hline
\end{tabular}

Key Words:

teaching materials; biography of ibnu hadjar; critical thinking

\begin{tabular}{l} 
ABSTRACT \\
\hline Abstract: The purpose of this research is to improve capability of critical thingking of \\
the student which relates to historical local figure of South Borneo. The realization of this \\
research is research and develpoment (R\&D). The explanation of Ibnu Hadjar's figure \\
was realized in the form of Ibnu Hadjar's biography teaching material supplement \\
products for students of history education offering B class of 2019 as an experimental \\
class and Offering A as a control class at Lambung Mangkurat University who were \\
taking Local History courses. The stages in this study use the 4D model that is indicated \\
by four components, namely identification, design, development, and dissemination. The \\
results of product validation and assessment include learning media expert validators with \\
a percentage of up to 77\% and are categorized as feasible to be implemented. The \\
assessment of the material experts obtained a percentage of $91 \%$ with the category very \\
feasible to be implemented. Obtaining language validation reached a percentage of $82 \%$ \\
and included in the category eligible to be implemented. The student's assessment of \\
teaching material supplement products reaches a percentage of 93\% with a very good \\
category. Assessment of lecturers supporting Local History courses obtained a percentage \\
of $85 \%$ and can be categorized as interesting. As for the results of the effectiveness of the \\
process of implementing the supplementary product of Ibnu Hadjar's biography teaching \\
material to improve the critical thinking skills of students in the experimental class gained \\
$82 \%$ percentage. This is very different from the results of students' critical thinking skills \\
in the control class that were not given and implemented biography teaching material \\
supplement products Ibnu Hadjar. The percentage gained in the control class only reached \\
$56 \%$.
\end{tabular}

\section{Correspondence:}

Febri Irwandi

History Education

State University of Malang

Semarang Street, 5 Malang City-East Java, Indonesia

E-mail: febrics7@gmail.com

The essence of history education is oriented toward understanding past events comprehensively and objectively. Understanding past events must be fair and wise without recognizing the orientation of historical distortions. One of the phenomenal figures of warriors in South Kalimantan is Ibnu Hadjar. In general, this figure was understood as a traitor by the Old Order government. However, the Banjar and Dayak people understood him to be a local fighter who was anti-colonialism in colonialism and foreign imperialism (Dijk, 1993). For the people of South Kalimantan in general, Ibnu Hadjar is a controversial figure who is in the middle between a traitor to the nation and a hero. This status orientates confusing thinking in perceiving Ibnu Hadjar's position as a heroic figure in South Kalimantan. The majority of local people consider him a charismatic hero. Ibnu Hadjar fulfills charismatic characteristics, including quality, knowledge, integrity, responsible, and high social (Zulkifli, 2016). On the other hand, the Old Order government called him a rebel, and he was executed at the hands of government executioners because he was accused of being involved in the Darul Islam movement or the Indonesian Islamic Army. The essence of the reality of South Kalimantan's people states that the figure of Ibnu Hadjar is a hero who struggles to eliminate the existence of colonialism in South Kalimantan. Based on a local historical perspective, Ibnu Hadjar is considered a charismatic, heroic, and freedom fighter (Noor, 2017). Understanding optimization in history learning should not only lie on one side but on both sides that are fair and objective, such as between a national perspective and a local perspective. Things related to multiple interpretations will be understood objectively when they are fairly explained verbally and in writing (Klein, 2010). The teaching material supplement developed by the researcher in this paper is a teaching material supplement that orientates Ibnu Hadjar's figure based on authentic historical local facts without any intervention from the perspective of the Old Order government. Problematic and ambivalence behind Ibnu Hajar's figure is not so recognized by students, due to the lack of teaching materials specifically, that discusses heroism and struggle of the figure of Ibnu Hajar in pure local historical facts related by Ibnu Hadjar. 
The purpose of studying history in universities and colleges is to apply and educate students through applicable, historical, and pedagogical values. Cognitive aspects are not only sufficiently implemented in history subjects; lecturers and teachers must be able to instill historical pedagogical values and historical awareness in students (Senen \& Barnadib, 2000). Teachers or lecturers must instill historical empathy in students, because basically historical empathy is the essence of historical thinking. A history teacher must orient historical feelings and emotions so that students can reflect historical values into the reality of their life, which is oriented to historical noble values (Siti Hawa Abdullah \& Aini Hassan, 2007). One of the steps developed by the developer in this research is to develop a product in the form of a supplement to Ibnu Hadjar's biography teaching materials to increase the sense of historical awareness and critical thinking ability of undergraduate students of history education study program who are taking local history courses at Lambung Mangkurat University, Banjarmasin. This teaching material supplement is basically included in the non-textbook for lectures. The book is a book that is not directly used as a compulsory book in the learning process in one subject or field of study in educational institutions (Pusat Perbukuan Depdiknas, 2008).

Teaching material supplements are books that contain teaching materials for certain subjects, with the composition of learning materials that are applied as a complement to the main handbook (Santyasa, 2002). Teaching material supplement books can also be interpreted as additional reference books to complement mandatory books in educational institutions (Pusat Perbukuan Depdiknas, 2008). Teaching material supplements function to describe certain subjects related to certain subjects / subjects in a broader, more specific, informative and in depth manner (Sitepu, 2012). Teaching materials are a collection of integrative components from systematic and structured learning materials. Teaching materials can also be interpreted as collections of knowledge that have been prepared based on the curriculum and core standards as well as competency standards, which include knowledge, skills, and attitudes. Teaching materials are taught by teachers and educators to students based on formal and informal curriculum references (Kurniawati, 2015). The teaching material component must have an informative, instructional orientation and be a learning facility for students (Tomlinson, 2012). A good teaching material component actually has a detailed and systematic composition based on the standard principles of learning competence (Sungkono, 2009). The teaching materials developed by the developer orient a biographical format that tells and explains the heroism and struggle of Ibn Hadjar in South Kalimantan. A biography is a description and explanation of the reality of a person's life history written by other people, whether the person is alive or dead. The description of a curriculum vitae written by oneself is referred to as an autobiography (Daud, 2013). The main purpose of writing a biography is to universally provide inspiration, wisdom, and struggle of certain figures to others so that everyone can know the valuable life experiences of the narrated characters (Jayanti et al., 2015). The substance of a biography contains valuable life experiences, the spirit of the reality of struggle, the toughness of life and inspirational values for life (Sari, 2011).

The product developed by the researcher basically connects the essence of critical thinking with regard to historical material that is controversial and ambivalent. Ibnu Hadjar's character, which is oriented towards multiple interpretations, especially in the local paradigm, is rarely explained by history lecturers, historians and history teachers in South Kalimantan. The national perspective is contradictory and not objective as a historical paradigm without understanding regional ethnographies and local historical perspectives (Evans, 2016). Thinking critically is a potential skill in applying the mind to know the essence and principle of truth (Subekti, 2018). Absolute penetration of critical thinking aims to open up essential truths and provide clear explanations for something unfinished and vague (Budi, 2016). Critical thinking includes the ability to process various critical opinions and questions in an integrative manner which then finds actual, credible, and reliable answers (Browne \& Keeley, 2015). The critical thinking component also includes emotion, intuition, sensing, and responsiveness in questionable (Vanicheva, Kah, \& Ponidelko, 2015). The power of critical thinking is greatly influenced by the power of interpretation and deduction of one's personality (Emir, 2009). Through critical thinking activities, contributions will be obtained in terms of thinking skills such as creating meaning, understanding events, dynamizing events, and having the potential to interpret everything in the final stage (Aliakbari \& Sadeghdaghighi, 2013). Critical reasoning contributes to individual progressivity in one's competence (Cavus \& Uzunboylu, 2009).

The characteristics of the teaching material supplement book include (1) the teaching material supplement book does not become a compulsory handbook for students or college students when participating in certain subjects or courses, (2) does not contain questions, tests, exams, tests, student worksheets, or else, (3) there is no level limitation to the use of books for certain classes, but only as a complement to learning, (4) oriented from competency standards or basic competency of all contents and descriptions of books, (5) can be used by anyone from all levels of education, (6) can be used as an enrichment material, reference source, and guide for educators (Pusat Perbukuan Depdiknas, 2008). The use of teaching material supplements as a complement to the main teaching materials is very helpful in the actualization process of learning transformation in the college student environment (Alfian, 2017).

The data obtained from observations and interviews at Lambung Mangkurat University on April 8, 2018, can be seen as follows. (1) Explanation Local history lessons related to the struggle of Ibnu Hadjar during the physical revolution in South Kalimantan and the Dutch Military Aggression were not conveyed comprehensively. (2) The description of the character Ibnu Hadjar has a complex material coverage, but it is still minimally delivered by the lecturer in totality, thus affecting students' critical power. (3) The lack of complexity in the availability of books discussed from a local perspective related to Ibnu Hadjar in the History Education Study Program of Lambung Mangkurat University. (4) Lecturers prefer to be careful and objective when explaining the controversial history. The limitations of teaching materials and the few references used can be proven by only 
using unspecified notes and books. As for the stages in history learning to achieve maximum value, lecturers who teach local history courses should use innovative, creative, and simple learning media. In the form of textbooks, supplements, visual media, and interactive media in the history learning process. The use of instructional media, although it is known to be very useful, has not been fully optimized (Sayono, 2013).

Based on the problems that have been stated above, it can be seen that lecturers and students need complementary sources of teaching materials in the form of teaching material supplements to optimize the local history learning process. The supplement of Ibnu Hadjar's biography teaching materials is used to open up the latest insights and horizons related to local historical facts of Ibnu Hadjar's figure, which contain values of struggle and heroism. It makes it easy for lecturers who teach local history courses to explain the figure of Ibn Hadjar in a fair, objective, and locally centric manner. Likewise with students, through the supplement of Ibnu Hadjar's biography teaching materials, students do not experience difficulties in understanding local historical facts related to the figure of Ibnu Hadjar, so that the critical power of students is connected when seeing complex and controversial events.

\section{METHOD}

The type of research used in this research is research and development. Development research in education is a process for developing products that are effective in learning activities and are not included in the theoretical testing phase (Gay, 1991). The development model is a term used in development research to describe a systematic and instructional approach. Development research has various types of models, according to the needs of educational products to be made or to develop existing products (Clay, 2009). The research and development method is a method or stage of research to produce a product and to test the effectiveness of the resulting product (Sugiyono, 2011). Research and Development (R\&D) can also be interpreted as developing new products or updating previous products and can be accounted for (Winarni, 2018). These research and development use a type of Four-D model. This Four-D development model is used because it has structured and systematic steps. The Four-D development model consists of four stages, namely: define, design, develop, and disseminate. These stages are interpreted as 4D, namely: definition, design, development, and distribution (Thiagarajan et al., 1974). The Four-D development model's application is used because at its stages, and it has a simple and practical nature when implemented. The Four-D development model is very suitable for developing teaching materials such as modules, student worksheets, textbooks, and teaching material supplements (Ernawati, 2014).

The Four-D development model includes four stages, namely. First, the defining stage, this stage analyzes the research needs, such as analysis of teaching materials, student analysis, preliminary observations, interviews with students and lecturers who teach local history courses. This activity is carried out to determine the materials' completeness that will be used in developing the product. Second, the design stage, at this stage the design construction of the product that will be designed is carried out according to the field defining analysis. Third, the development stage, this stage is the development of a product that is integrated with the previous stages. The product developed is then validated by material experts, product experts and linguists so that the product is valid and has good credibility, so that the product developed is feasible to be implemented in the field. The feasibility test used is a material experts' questionnaire instrument, product experts, and linguists. A valid and feasible product will then be easy to apply to students. Fourth, the disseminate stage, this stage is the final step in product completion. Dissemination of products that are valid and feasible is then disseminated through journal articles and the formation of published biographies of Ibnu Hadjar. The biographical book will be distributed to students of class 2017 offering B and lecturers who teach local history courses at the History Education Study Program of FKIP, Lambung Mangkurat University, which is located on Jl. Brigjen H. Hasan Basri, Pangeran, North Banjarmasin District, Banjarmasin City. The trial phase was carried out in two stages, namely small group trials and large group trials. The large group trial is divided into two stages, namely the control and experimental classes. The control class was not given a product and the experimental class was given a product with the aim of comparison to determine the level of students' critical thinking skills. The number of students offering B is 28 students, consisting of 15 male students and 13 female students. As for the number of students offering A as many as 31 students.

The validity qualifications of the biography teaching material supplements of Ibnu Hadjar will be very valid if they meet the percentage $(70.00-100.00 \%)$ and can be used without revision correction. The next stage is quite valid when it meets the percentage $(60.00-69.00 \%)$ and can be used but requires a little revision. In the last stage, if it only reaches a percentage (50.00$59.00 \%)$, it can be ascertained that the product being developed is declared less valid and requires major revisions. Meanwhile, when the percentage only reaches $(00.00-49.00 \%)$, the product is invalid/feasible and requires major revisions with great care (Arikunto, 2006).

\section{RESULTS}

The following are the result of the stages of developing Ibnu Hadjar's biography teaching material supplements to improve students' critical thinking skills. The result can be saw in table 1. 
Table 1. Finding Result

\begin{tabular}{clcl}
\hline No. & \multicolumn{1}{c}{ Assesment } & Percentage (\%) & \multicolumn{1}{c}{ Information } \\
\hline 1. & Media/learning product expert & 77 & Feasible and can be implemented \\
2. & Material expert & 91 & Very feasible and implementable \\
3. & Linguists & 82 & $\begin{array}{l}\text { Very feasible and implementable } \\
\text { Teaching materials supplements are } \\
\text { interesting \& practical }\end{array}$ \\
4. & Assesment of teaching material by a lecturer & 85 & $\begin{array}{l}\text { Interesting \& practical teaching } \\
\text { material supplements }\end{array}$ \\
5. & $\begin{array}{l}\text { Assesment of teaching material supplements by } \\
\text { students (small group trial) }\end{array}$ & 91 & $\begin{array}{l}\text { Student critical thinking ability } \\
\text { failed }\end{array}$ \\
6. & $\begin{array}{l}\text { Explanation of Ibnu Hadjar material without } \\
\text { supplementary teaching materials (control class) }\end{array}$ & 56 & $\begin{array}{l}\text { Student critical thinking ability is } \\
\text { satisfactory }\end{array}$ \\
\hline
\end{tabular}

Based on the results of the explanation of the assessment above, it can be seen that Ibnu Hadjar's biography teaching material supplement is a local history learning product that can be applied as a complementary component of learning in addition to the main book and supporting lecturers' narratives related to material on the Physical Revolution and Dutch Military Aggression in South Kalimantan. The series of valid product validation results from experts on teaching material supplement products shows that the product is feasible to be implemented to students. The validation assessment of instructional media/product experts shows that the supplement product is feasible to be realized in the form of a teaching material supplement book. Furthermore, from the expert's assessment, the material described is under the local perspective of the people of South Kalimantan. Language validation shows that the product being developed is feasible in terms of writing and can be read according to the correct rules. The assessment from the lecturer who teaches the local history course on this teaching material supplement product is very satisfying. It can be seen from the data above that the lecturers give good appreciation regarding the teaching material supplements.

\section{DISCUSSION}

\section{Product Development Supplement for Ibnu Hadjar Biography Teaching Materials}

Realization of the product developed by the researcher is a simple book in the form of a teaching material supplement that complements learning materials in the Local History course. The resulting product is a supplement to Ibnu Hadjar's biography teaching materials for students. Before implementing this teaching material supplement in the trial phase, the validation phase is first carried out. The results of the validation of the instructional media expert obtained a score of $77 \%$, which was included in the fairly valid category. Input from the instructional media expert validator was in the form of a suitable layout correlation between images and narration, improved layout, and design covers a more dynamic based on Ibnu Hadjar's local heroism. Furthermore, the score reached $91 \%$ in the valid category from the material expert validation and could be implemented in the field. The material expert validator provides input to add to the book title's perfection with the words Supplement for Ibnu Hadjar Biography Teaching Materials Based on Local Perspectives. The next stage is the validation of the linguist with a score of $82 \%$. The score is categorized as quite valid. Inputs obtained from linguist validators include writing improvements such as periods, commas, conjunction inconsistencies, capital letters, and narrative actualization by paying attention to writing grammar. The essence of the validation of these experts is that the products developed are valid and feasible to be implemented to students.

Inputs and suggestions from the validator are then used as material for improvement before the students' product application process. The product developed in the form of a complementary book, namely a supplement to Ibnu Hadjar's biography teaching materials, is as a whole for students of the Teacher Training and Education Faculty of History Education Study Program, Lambung Mangkurat University, Banjarmasin class of 2017 or semester four who are taking Local History courses. The teaching material supplement was developed with a basic competency orientation in the Local History course, namely the Physical Revolution Period in South Kalimantan and the Dutch Military Aggression in South Kalimantan. The penetration of Ibn Hadjar's heroism was very dominant at these times. The small group trial was held on May 6, 2019, which consisted of 9 students. The student selection classification is categorized into high, medium, and low potential students. The students were given a questionnaire to assess the supplement book's practicality and attractiveness for Ibnu Hadjar's biography teaching materials. Meanwhile, the data from the small group test reached a percentage of $93 \%$. Based on this figure's results, it can be said that the teaching material supplement book product is categorized as valid and can be continued in the implementation of large group trials. The next step after the implementation of the small group trial is the large group trial. In addition to distributing questionnaires to students, researchers also gave questionnaires to the product's attractiveness and practicality to lecturers who taught Local History courses. The score obtained from the questionnaire given to lecturers reached a percentage of $85 \%$. The questionnaire results' responses indicate that the teaching material supplements developed are very interesting and practical to be implemented as a complement to student teaching materials. 
The large group trial results reached a percentage of 90\%, which indicated that the supplement of Ibn Hadjar's biography teaching materials could be implemented as a complement to teaching materials that were valid, systematic, interesting, and practical.

This study also applies a questionnaire instrument to determine how much historical awareness of students is related to the orientation of the local figure of South Kalimantan, Ibnu Hadjar. The questionnaire given to students must be in accordance with the indicators of historical awareness, which include (a) living the meaning and essence of history for the present and the future, (b) knowing themselves and their nation, (c) civilizing history for the development of national culture, and (d) maintaining the nation's historical heritage (Aman, 2011). The next historical indicators include an understanding, views, thoughts, and constructions of the past as a daily life process (Subagyo, 2010). Researchers also relate historical awareness indicators with awareness orientation in the form of mental activities with the reality of thoughts, ideas, emotions, desires, and memories stored personally when a person thinks about things in their environment (Kuper \& Kuper, 2002).

The historical awareness questionnaire that was realized for students had the criteria of strongly agree, agree, disagree, and strongly disagree. The acquisition of historical awareness questionnaire scores reached a percentage of $90 \%$ and can be categorized as successful. Meanwhile, to determine the increase in students' critical thinking skills related to the figure of Ibnu Hadjar, the researcher gave 20 multiple choice questions oriented with indicators of critical thinking skills and taxonomy bloom skills indicators include Critical thinking problem solving, creative-innovative, communicative and collaborative. Critical thinking is a high-level cognitive skill, such as the ability to argue, analyze and evaluate processes (Subekti, 2018). Based on the acquisition of student historical awareness questionnaire data scores which reached a percentage of $90 \%$ and the results of students' critical thinking skills, which reached a percentage of $82 \%$, it can be concluded that Ibnu Hadjar's biography teaching material supplement which is used as a learning complement to the Local History course can increase the sense of ability critical thinking and historical awareness of students related to the orientation of Ibnu Hadjar's figure, which so far has ambivalence of meaning related to this figure.

\section{CONCLUSIONS}

The development products produced through this study aim to hone students' critical thinking skills. Students' critical thinking skills can be optimized through the potential for realistic and authentic understanding. The status of a figure who is considered controversial and full of ambivalence can be objectively understood by conducting an actual and competent study. This can be applied by understanding figures who are naturally ambivalent with local historical facts. Local-centric facts can be obtained through oral studies, such as understanding local perspectives based on historical facts in the figure's area objectively. This supplement to Ibn Hadjar's biography teaching materials is expected to be a choice in understanding Ibnu Hadjar's heroism based on a local historical perspective. Ibnu Hadjar's heroism facts need to be explained comprehensively so that there is no historical distortion related to local figures in South Kalimantan. This supplement of teaching materials needs to be redeveloped to support innovation and creativity in learning local history for students so that the essence and historical heroism of figures in South Kalimantan is not degraded and disappear.

The development of teaching materials, learning media, textbooks, supplements, and modules still needs to be developed thoroughly both in the higher education environment and from basic education. Updates and innovations in learning local history need to be realized in totality so that local historical values in South Kalimantan always exist and are not lost. The use of technology that is increasingly developing today can be combined with learning local history so that the authenticity of thought patterns and historical understanding is realized based on local perspectives. This research hopes that it can inspire other researchers to explain in-depth related to local heroism and local history, which has not been fully realized in academic activities.

\section{REFERENCES}

Alfian, S. Y. (2017). Mengajarkan Sejarah Tanpa Membosankan. Surabaya: Pustaka Media Guru.

Aliakbari, M., \& Sadeghdaghighi, A. (2013). Teachers' Perception of the Barriers to Critical Thinking. Procedia - Social and Behavioral Sciences, 70, 1-5. https://doi.org/10.1016/j.sbspro.2013.01.031

Aman. (2011). Model Evaluasi Pembelajaran Sejarah. Yogyakarta: Penerbit Ombak.

Arikunto, S. (2006). Instrumen Pembelajaran. Bandung: Rosdakarya.

Browne, M. N., \& Keeley, S. M. (2015). Pemikiran Kritis Panduan untuk Mengajukan dan Menjawab Pertanyaan Kritis. (B. R. Daffi, Ed.) (10th ed.). Jakarta: Indeks.

Budi, J. F. S. (2016). Berpikir ala Einsten dan Bertindak ala Gandhi. Yogyakarta: Diva Press.

Cavus, N., \& Uzunboylu, H. (2009). Improving Critical Thinking Skills in Mobile Learning. Procedia - Social and Behavioral Sciences, 1(1), 434-438. https://doi.org/10.1016/j.sbspro.2009.01.078

Daud, S. (2013). Antara Biografi dan Historiografi (Studi 36 Buku Biografi di Indonesia). Analisis: Jurnal Studi Keislaman, $3(1), 243-270$.

Emir, S. (2009). Education Faculty Students' Critical Thinking Disposition According to Achedemic Achievement. Procedia Social and Behavioral Sciences, 1(1), 2466-2469. https://doi.org/10.1016/j.sbspro.2009.01.433

Ernawati. (2014). Pengembangan Perangkat Pembelajaran Berdasarkan Model 4-D Pada Materi Getaran Gelombang dan Bunyi Dalam Meningkatkan Pemahaman Konsep Siswa SMP Negeri 6 Palu. Jurnal Sains dan Teknologi Tadulako, 3(1), 62-71. 
Evans, M. (2016). The Accidental Guerrilla: Fighting Small Wars in the Midst of a Big One. Small Wars \& Insurgencies, 2318(June), 197-200. https://doi.org/10.1080/09592318.2012.632871

Gay, L. R. (1991). Educational Evaluation and Measurement: Competencies for Analysis and Application (2nd ed.). New York: Macmillan Publishing Compan.

Jayanti, T., Nuryatin, A., \& Mardikantoro, H. B. (2015). Pengembangan Buku Pengayaan Menulis Cerita Biografi Bermuatan Nilai-Nilai Pendidikan Karakter bagi Peserta Didik Kelas VIII SMP. Seloka: Jurnal Pendidikan Bahasa dan Sastra Indonesia, 4(2), 65-71. https://doi.org/10.15294/seloka.v4i2.9862

Klein, S. R. E. (2010). Teaching History in the Netherlands: Teachers' Experiences of a Plurality of Perspectives. Curriculum Inquiry, 40(5), 614-634. https://doi.org/10.1111/j.1467-873X.2010.00514.x

Kuper, A., \& Kuper, J. (2002). Ensiklopedi Ilmu-Ilmu Sosial (2nd ed.). Jakarta: Rajawali Press.

Kurniawati, F. E. (2015). Pengembangan Bahan Ajar Aqidah Ahklak di Madrasah Ibtidaiyah. Jurnal Penelitian, 9(2), 367-388.

Noor, Y. (2017). Hassan Basry, Ibnu Hadjar, dan Mitos Harta Karun Ibnu Hadjar. In Prosiding Seminar Nasional Pendidikan Sejaran. Banjarmasin: Universitas Lambung Mangkurat.

Pusat Perbukuan Depdiknas. (2008). Pedoman Penilaian Buku Nonteks Pelajaran. Jakarta: Departemen Pendidikan Nasional.

Sari, D. H. (2011). Biografi Siti Manggopoh sebagai Sumber Kearifan Lokal untuk Meningkatkan Motivasi Belajar Siswa dalam Pembelajaran Sejarah (Studi Kasus pada Siswa MAN Koto Kecil Kabupaten Agam Propinsi Sumatera Barat). Marwah: Jurnal Perempuan, Agama, dan Jender, 10(1), 1-16.

DOI: http://dx.doi.org/10.24014/marwah.v10i1.482

Sayono, J. (2013). Pembelajaran Sejarah di Sekolah: Dari Pragmatis ke Idealis. Jurnal Sejarah dan Budaya, 7(1), $109-123$.

Senen, A., \& Barnadib, I. (2000). Tantangan Guru Sejarah: Pesan Sejarah sebagai Konsep Pendidikan Nilai. Jurnal Penelitian dan Evaluasi Pendidikan, 3(2), 131-140. https://doi.org/10.21831/pep.v2i3.2090

Sitepu, B. P. (2012). Penulisan Buku Teks Pelajaran. Bandung: Remaja Rosdakarya.

Siti Hawa Abdullah, \& Aini Hassan. (2007). Empati Sejarah dalam Pengajaran dan Pembelajaran Sejarah. Malaysian Journal of Educators and Education, 22, 61-74.

Subagyo. (2010). Membangun Kesadaran Sejarah. Semarang: Widyakarya.

Subekti, S. (2018). Mencetak Generasi Cerdas Melalui Berpikir Kritis. Surabaya: Cipta Media Edukasi.

Sugiyono. (2011). Metode Penelitian Kuantitatif, Kualitatif, dan R\&D. Bandung: Alfabeta.

Sungkono. (2009). Pengembangan dan Pemanfaatan Bahan Ajar Modul dalam Proses Pembelajaran. Majalah Ilmiah Pembelajaran, 1(1), 1-13.

Thiagarajan, S., Semmel, D. S., \& Semmel, M. I. (1974). Instructional Development for Training Teachers of Exceptional Children (Vol. 74). Minneapolis, Minnesota: Leadership Training Institute/Special Education, University of Minnesota.

Tomlinson, B. (2012). Materials Development for Language Learning and Teaching. Language Teaching, 45(2), $143-179$. https://doi.org/10.1017/S0261444811000528

Vanicheva, T., Kah, M., \& Ponidelko, L. (2015). Critical Thinking within the Current Framework of ESP Curriculum in Technical Universities of Russia. Procedia - Social and Behavioral Sciences, 199, 657-665. https://doi.org/10.1016/j.sbspro.2015.07.595

Winarni, E. W. (2018). Teori dan Praktik Penelitian Kuantitatif Kualitatif Penelitian Tindakan Kelas (PTK). Jakarta: Bumi Aksara.

Zulkifli. (2016). Pengajian Tasawuf K. H. Muhammad Ridwan Baseri di Majelis Taklim Al-Hidayah Hulu Sungai Selatan (Telaah Karisma dan Tasawuf Modern). Al-Banjari, 15(1), 1-14. 